\title{
ACTIVITY OF NITROGEN FIXATION IN LUCERNE AGROCENOSES AND PRODUCTIVITY OF CULTURE UNDER INFLUENCE OF FERTILIZERS AND MICROBIAL PREPARATION
}

\author{
L. V. Tsentilo \\ National University of Life and Environmental Science of Ukraine, Kyiv, Ukraine, \\ e-mail: agrokolos@i.ua
}

In a long field experiment on common black soil, the influence of various fertilization systems and presowing bacterization of seeds on the activity of symbiotic nitrogen fixation in lucerne agrocenoses and crop productivity was studied. Stimulation of the process of fixation of atmospheric nitrogen was observed when mineral fertilizers were used in the doses not exceeding $N_{60} P_{60} K_{60}$, when they were introduced in the year of sowing. High rates of nitrogenase activity were noted in conditions of aftereffect of manure, compost, organic mineral fertilizer (manure $+N_{30} P_{30} K_{30}$ ), as well as systematic use of crop residues in the crop rotation. The plant mass in above variants was characterized by high protein content. At the same time, the greatest influence on protein synthesis was provided by the use of a microbial preparation. The combination of ecologically acceptable agricultural backgrounds with presowing bacterization of lucerne seeds ensured the obtaining of parameters of crop productivity.

Key words: alfalfa, fertilization systems, nitrogen fixation, protein content.

Medic or blue alfalfa (Medicago sativa L.) is the main bean culture in the feed conveyor system. The benefits of alfalfa to other herbs are high yields over several years, feed value, adaptation to different soil-climatic conditions. Alfalfa plants quickly grow after mowing, the yield of green mass can reach 40-60 t/ha, hay - 5-10 t/ha and more.

Alfalfa has an important agricultural value. By forming a powerful root system, it contributes to the enrichment of soil with nutrients, especially nitrogen, improves its physical properties. According to the literary data, agrocenoses with this culture bind 140 to $300 \mathrm{~kg}$ of nitrogen per hectare $[1 ; 2]$. However, under different crop fertilization systems in crop rotation, the productivity of nitrogen fixation under alfalfa can be significantly changed, including towards decreasing parameters. In this regard, the purpose of our work is to study the influence of agricultural backgrounds in the cultivation of alfalfa on the activity of the process of symbiotic nitrogen fixation and culture productivity.

Materials and methods. The study was conducted in 2011-2015 under conditions of a longterm field experiment of the National University of Biological Resources and Environmental 
Management of Ukraine and the Institute of Agricultural Microbiology and Agroindustrial Manufacture of the National Academy of Agrarian Sciences of Ukraine on typical black soil (content of humus $-4.04 \%$, readily hydrolyzed nitrogen $-21.7 \mathrm{mg} / \mathrm{kg}$, exchangeable $\mathrm{K}_{2} \mathrm{O}-$ $\left.22.6 \mathrm{mg} / \mathrm{kg}, \mathrm{P}_{2} \mathrm{O}_{5}-52.5 \mathrm{mg} / \mathrm{kg}, \mathrm{pN}_{\mathrm{sol}}-5.37\right)$. The experiment is located Agrarian Company KOLOS, LLC (District of Skvyra, Region of Kyiv). Medic of Lidia variety was cultivated in crop rotation: peas - winter wheat - winter rape - soybean - sunflower - alfalfa - corn.

The experiment provides two equivalent blocks of variants - without bacterization and with pre-sowing bacterization of seeds.

Variants of culture fertilization in both blocks are as follows:

1. Without fertilizers, control;

2. $\mathrm{N}_{30} \mathrm{P}_{30} \mathrm{~K}_{30}$;

3. $\mathrm{N}_{60} \mathrm{P}_{60} \mathrm{~K}_{60}$;

4. $\mathrm{N}_{90} \mathrm{P}_{90} \mathrm{~K}_{90}$;

5. $\mathrm{N}_{120} \mathrm{P}_{120} \mathrm{~K}_{120}$;

6. Cattle manure, $25 \mathrm{t} / \mathrm{ha}$ (the fourth year after-effect);

7. Cattle manure, $12.5 \mathrm{t} /$ ha (the fourth year after-effect) $+\mathrm{N}_{30} \mathrm{P}_{30} \mathrm{~K}_{30}$;

8. Biocompost, $12.5 \mathrm{t} / \mathrm{ha}$ (the fourth year after-effect);

9. Plant remnants (direct effect of $3 \mathrm{t} / \mathrm{ha}$ of sunflower remnants + the first year after-effect 3 t/ha of soybean remnants + the second year after-effect 3 t/ha of rapeseed remnants + the third year after-effect $4 \mathrm{t} / \mathrm{ha}$ of wheat straw + the fourth year after-effect $3 \mathrm{t} / \mathrm{ha}$ of pea straw).

Mineral fertilizers were introduced into culture only in the first year of life of plants.

The repetition of the experiment is four-fold, the total area of one plot is $200 \mathrm{~m}^{2}$, and the accounting area is $160 \mathrm{~m}^{2}$. Placement of plots is systemic.

For pre-sowing bacterization of wheat seeds, the microbial preparation Rhizobofit on the basis of Sinorhizobium meliloti 425a was used.

As a compost, the bioconversion product of manure, obtained from the method developed by us under the use of an aerator PT-120 and suspension of microorganisms (an application to the State patent of Ukraine for an invention is presented) was used.

Spring sowing was performed. The seed sowing rate is $18 \mathrm{~kg} / \mathrm{ha}$ ( 9 million similar seeds per hectare). The seeds were sown in an ordinary row way with a row width of $12.5 \mathrm{~cm}$. The depth of wrapping is $2-3 \mathrm{~cm}$.

Over the time, during the first and second years of culture vegetation, the activity of nitrogen fixation by acetylene method [3] was determined on the plant roots. The crop was recorded by pslots. At the same time, in the first year of the plant life, two cuts were carried out, in the second 
year of vegetation - four, in the third year - one cut, after which the field was plucked and buckwheat (a yield culture) was sown. The protein content in green mass was determined by photometry according to DSTU [4].

The statistical processing of the obtained results was carried out using analysis of variance [5] and a computer program (Microsoft Office Excel 2003-2007).

Results and discussion. Indicators of nitrogen fixation activity in rhizospheric soil of plants are proposed to use as a kind of indicator of the expediency of nitrogen fertilizer rates [6]. At the same time, the growth of activity compared with the control variant (without the introduction of mineral nitrogen) is the evidence of the environmental feasibility of fertilization, respectively, reducing the intensity of the process is a reflection of excess supply of soil with mineral nitrogen compounds.

According to the aforementioned, all the mineral backgrounds were excessive in the booting phase for the functioning of symbiotic nitrogen fixation. Pre-sowing bacterization of seeds under the use of Rhizobofit somewhat offset this effect, but to a small extent.

The following was favourable for the nitrogen fixation process: manure after-effect, biocompost after-effect, and the use of plant remnants. The positive effect of Rhizobofit on the functioning of bean-rhizobial symbiosis was intensified by this agricultural backgrounds (Table 1).

In the next phase of organogenesis of alfalfa plants, the growth of nitrogenase activity was observed in virtually all of the agricultural backgrounds, with the exception of the largest dose of mineral fertilizers. Stimulation of activity should be noted following the introduction of $\mathrm{N}_{30} \mathrm{P}_{30} \mathrm{~K}_{30}$ and especially following the use of microbial preparation. The use of mineral fertilizers in the normal range of $\mathrm{N}_{60} \mathrm{P}_{60} \mathrm{~K}_{60}$ provided a tendency to decrease in activity compared to control. Higher rates of mineral fertilizers compared with mentioned above provided a significant reduction of nitrogenase activity. After-effect of organic fertilizers positively affected nitrogen fixation. At the same time, Rhizobofit provided one of the highest rates in the experiment.

During the flowering phase, stimulation of the activity of nitrogen fixation was noted under the use of the smallest range of mineral fertilizers in the experiment. The use of $\mathrm{N}_{60} \mathrm{P}_{60} \mathrm{~K}_{60}$ in this period no longer had a negative impact on the studied process, and in combination with the microbial preparation, provided an increase in activity. The higher experimental ranges of mineral fertilizers inhibited the activity of nitrogen fixation, and during the use of Rhizobofit by this agricultural backgrounds, only slightly increased the nitrogenase activity. As in the previous phases of organogenesis of plants, organic fertilizers contributed to a significant increase in the activity of symbiotic nitrogen fixation, especially under the use of a microbial preparation. 
Table 1. The symbiotic nitrogen fixation activity under influence fertilizers and Rhizobofit, 2014

\begin{tabular}{|c|c|c|c|}
\hline \multirow[t]{2}{*}{ Variants of experiment } & \multicolumn{3}{|c|}{$\begin{array}{c}\text { Nitrogenase activity, } \\
\text { nmol } \mathrm{C}_{2} \mathrm{H}_{4} / \text { plant per hour }\end{array}$} \\
\hline & Booting stage & Budding stage & Flowering stage \\
\hline \multicolumn{4}{|c|}{ without bacterization } \\
\hline Without fertilizers, control & 6,3 & 7,2 & 7,9 \\
\hline $\mathrm{N}_{30} \mathrm{P}_{30} \mathrm{~K}_{30}$ & 4,9 & 8,0 & 10,1 \\
\hline $\mathrm{N}_{60} \mathrm{P}_{60} \mathrm{~K}_{60}$ & 3,7 & 6,8 & 8,0 \\
\hline $\mathrm{N}_{90} \mathrm{P}_{90} \mathrm{~K}_{90}$ & 1,4 & 4,7 & 5,2 \\
\hline $\mathrm{N}_{120} \mathrm{P}_{120} \mathrm{~K}_{120}$ & 0,5 & 0,5 & 0,9 \\
\hline Cattle manure, 25 t/ha & 8,1 & 9,9 & 10,4 \\
\hline $\begin{array}{l}\text { Cattle manure, } 12,5 \mathrm{t} / \mathrm{ha} \quad+ \\
\mathrm{N}_{30} \mathrm{P}_{30} \mathrm{~K}_{30}\end{array}$ & 5,2 & 8,1 & 10,0 \\
\hline Biocompost, 12,5 t/ha & 8,9 & 10,3 & 12,0 \\
\hline Plant remnants & 7,5 & 8,5 & 11,5 \\
\hline \multicolumn{4}{|c|}{ bacterization with Rhizobofit } \\
\hline Without fertilizers & 7,1 & 8,8 & 9,5 \\
\hline $\mathrm{N}_{30} \mathrm{P}_{30} \mathrm{~K}_{30}$ & 6,5 & 10,1 & 12,8 \\
\hline $\mathrm{N}_{60} \mathrm{P}_{60} \mathrm{~K}_{60}$ & 4,1 & 8,0 & 11,4 \\
\hline $\mathrm{N}_{90} \mathrm{P}_{90} \mathrm{~K}_{90}$ & 1,6 & 5,5 & 6,1 \\
\hline $\mathrm{N}_{120} \mathrm{P}_{120} \mathrm{~K}_{120}$ & 0,4 & 0,7 & 1,1 \\
\hline Cattle manure, 25 t/ha & 10,4 & 12,8 & 13,9 \\
\hline $\begin{array}{l}\text { Cattle manure, } 12,5 \mathrm{t} / \mathrm{ha} \quad+ \\
\mathrm{N}_{30} \mathrm{P}_{30} \mathrm{~K}_{30}\end{array}$ & 6,3 & 11,0 & 12,5 \\
\hline Biocompost, 12,5 t/ha & 11,0 & 14,0 & 14,5 \\
\hline Plant remnants & 9,5 & 10,4 & 13,0 \\
\hline for experiment & 1,0 & 1,5 & 1,4 \\
\hline for fertilizers & 0,6 & 0,8 & 0,7 \\
\hline for inoculation and interaction & 0,4 & 0,8 & 0,7 \\
\hline
\end{tabular}

Measurement of the activity of symbiotic nitrogen fixation in the second year of culture vegetation, under the condition of after-effect of all agricultural backgrounds provided by the scheme of experiments, indicates certain changes in the peculiarities of the process. Thus, in particular, the after-effect of $\mathrm{N}_{60} \mathrm{P}_{60} \mathrm{~K}_{60}$ showed stimulation of nitrogenase activity. The after-effect of $\mathrm{N}_{90} \mathrm{P}_{90} \mathrm{~K}_{90}$ negatively affected nitrogen fixation activity only in the first phases of organogenesis, and in combination with Rhizobofit, it contributed to an increase in the parameters relative to absolute control (Table 2).

The after-effect of organic fertilizers contributed to the active course of the process in all phases of organogenesis of alfalfa plants. The combination of these fertilizers with Rhizobofit provided the manifestation of the highest experimental activity. At the same time, it is undoubtedly interesting that there is an option with the systematic application of plant remnants. As is known, in 
order to optimize the carbon-nitrogen ratio and avoid the immobilization of nitrogen compounds in agrocenosis soils, application of plant remnants requires about $10 \mathrm{~kg}$ of nitrogen per ton of straw [7]. However, upon cultivation in crop rotation in legumes, and especially perennials (alfalfa, clover, sainfoin), the need for additional soil provision with a compensatory dose of mineral nitrogen may not arise. This is due to the significant accumulation of nitrogen, absorbed in the conditions of the active course of symbiotic nitrogen fixation, in the root remnants of herbs, as well as root extracts enriched in nitrogen.

Table 2. The symbiotic nitrogen fixation activity under influence fertilizers and Rhizobofit, 2015

\begin{tabular}{|c|c|c|c|}
\hline \multirow[t]{2}{*}{ Variants of experiment } & \multicolumn{3}{|c|}{$\begin{array}{c}\text { Nitrogenase activity, } \\
\text { nmol } \mathrm{C}_{2} \mathrm{H}_{4} / \text { plant per hour }\end{array}$} \\
\hline & Booting stage & Budding stage & Flowering stage \\
\hline \multicolumn{4}{|c|}{ without bacterization } \\
\hline Without fertilizers, control & 15,8 & 18,4 & 17,2 \\
\hline $\mathrm{N}_{30} \mathrm{P}_{30} \mathrm{~K}_{30}$ & 17,3 & 23,0 & 24,1 \\
\hline $\mathrm{N}_{60} \mathrm{P}_{60} \mathrm{~K}_{60}$ & 15,7 & 19,8 & 22,0 \\
\hline $\mathrm{N}_{90} \mathrm{P}_{90} \mathrm{~K}_{90}$ & 11,5 & 15,5 & 17,2 \\
\hline $\mathrm{N}_{120} \mathrm{P}_{120} \mathrm{~K}_{120}$ & 4,1 & 6,5 & 6,9 \\
\hline Cattle manure, $25 \mathrm{t} / \mathrm{ha}$ & 18,1 & 24,9 & 25,4 \\
\hline $\begin{array}{l}\text { Cattle manure, } 12,5 \mathrm{t} / \mathrm{ha} \quad+ \\
\mathrm{N}_{30} \mathrm{P}_{30} \mathrm{~K}_{30}\end{array}$ & 17,0 & 22,1 & 25,2 \\
\hline Biocompost, 12,5 t/ha & 21,5 & 24,3 & 27,5 \\
\hline Plant remnants & 17,0 & 18,2 & 21,0 \\
\hline \multicolumn{4}{|c|}{ bacterization with Rhizobofit } \\
\hline Without fertilizers & 22,5 & 25,8 & 23,0 \\
\hline $\mathrm{N}_{30} \mathrm{P}_{30} \mathrm{~K}_{30}$ & 27,5 & 28,1 & 27,5 \\
\hline $\mathrm{N}_{60} \mathrm{P}_{60} \mathrm{~K}_{60}$ & 24,0 & 26,5 & 25,1 \\
\hline $\mathrm{N}_{90} \mathrm{P}_{90} \mathrm{~K}_{90}$ & 17,6 & 19,0 & 19,1 \\
\hline $\mathrm{N}_{120} \mathrm{P}_{120} \mathrm{~K}_{120}$ & 5,5 & 6,7 & 8,1 \\
\hline Cattle manure, 25 t/ha & 28,4 & 32,5 & 28,3 \\
\hline $\begin{array}{l}\text { Cattle manure, } 12,5 \mathrm{t} / \mathrm{ha} \quad+ \\
\mathrm{N}_{30} \mathrm{P}_{30} \mathrm{~K}_{30}\end{array}$ & 26,3 & 31,1 & 28,5 \\
\hline Biocompost, 12,5 t/ha & 31,0 & 27,0 & 30,5 \\
\hline Plant remnants & 19,0 & 26,4 & 27,0 \\
\hline for experiment & 2,2 & 2,5 & 1,8 \\
\hline for fertilizers & 1,2 & 1,3 & 0,9 \\
\hline for inoculation and interaction & 1,0 & 1,2 & 0,9 \\
\hline
\end{tabular}

The obtained results generally confirm this thesis. As we see, the highest parameters of atmospheric nitrogen binding are noted precisely in variants with organic fertilizers, including systematic use of plant remnants. 
As it is known, mineral nitrogen is one of the main factors in reducing the activity of nitrogen fixation. At the same time, peculiarities of alfalfa cultivation demonstrate the positive role of low ranges of mineral fertilizers in the entry of biological nitrogen in the plants.

High normal ranges of mineral fertilizers lead to a decrease in the activity of symbiotic nitrogen fixation, and therefore their use in the technology of alfalfa cultivation is inappropriate.

Accounting for the harvest of green mass of alfalfa shows the growth of indicators from the use of mineral fertilizers. However, the yield under each subsequent dose of mineral fertilizer is significantly reduced compared to the previous one. So, if the increment to the control without fertilizer from the introduction of $\mathrm{N}_{30} \mathrm{P}_{30} \mathrm{~K}_{30}$ amounted to $1.09 \mathrm{t} /$ ha of dry matter, then the next normal range of fertilizers in the experiment $\left(\mathrm{N}_{60} \mathrm{P}_{60} \mathrm{~K}_{60}\right)$ provided an increment at the level of 0.86 t/ha in comparison with the previous one $\left(\mathrm{N}_{30} \mathrm{P}_{30} \mathrm{~K}_{30}\right)$, and comparison of the effect from the application of $\mathrm{N}_{90} \mathrm{P}_{90} \mathrm{~K}_{90}$ and $\mathrm{N}_{60} \mathrm{P}_{60} \mathrm{~K}_{60}$ shows an increase in yield from the first one by only 0.47 t/ha (Table 3).

The after-effect of organic fertilizers is quite essential for the formation of alfalfa yield. Since this is the fourth year of the after-effect in the experiment, this effect is explained, moreover, not by nutrients, but by the influence of fertilizers on the general condition of the soil, including physicochemical parameters. The systemic application of straw in the experiment provides a tendency to increase the yield of the crop, which is extremely positive, given the possible development of immobilization processes in the soil when plant remnants are introduced, without taking into account the optimization of the carbon-nitrogen ratio.

When cultivating alfalfa, the most intensive factor influencing the formation of crop yield is the use of microbial preparation. However, the effect of Rhizobofit clearly depends on agricultural background. Thus, a significant increase in the crop in the experiment from pre-sowing bacterization was observed in the background without fertilizers, under the introduction of $\mathrm{N}_{30} \mathrm{P}_{30} \mathrm{~K}_{30}$ and $\mathrm{N}_{60} \mathrm{P}_{60} \mathrm{~K}_{60}$, as well as under the after-effects of organic fertilizers.

The use of Rhizobofit in growing the culture on the background of the $\mathrm{N}_{90} \mathrm{P}_{90} \mathrm{~K}_{90}$, as well as the $\mathrm{N}_{120} \mathrm{P}_{120} \mathrm{~K}_{120}$ demonstrates the smallest increment in the experiment. Moreover, the yields on the specified agricultural backgrounds are within the limits obtained under the use of Rhizobofit by the background of mineral fertilizers in the normal range of $\mathrm{N}_{60} \mathrm{P}_{60} \mathrm{~K}_{60}$ (and even there is a tendency to decrease in these parameters). Consequently, the combination of pre-sowing bacterization of alfalfa with mineral fertilizers backgrounds that exceeds $\mathrm{N}_{60} \mathrm{P}_{60} \mathrm{~K}_{60}$ is inappropriate.

Measurement of the content of protein (“crude protein") in the green mass of alfalfa suggests an increase in indicators for the application of mineral fertilizers (Table 4). However, linear growth of values is not observed and, as with the accounting of crop yields, we come to the conclusion that mineral fertilizers are expedient within $60 \mathrm{~kg}$ of active substance per hectare. 
Table 3. Alfalfa yields upon the application fertilizers and Rhizobofit

\begin{tabular}{|c|c|c|c|c|c|c|}
\hline \multirow[b]{2}{*}{ Variants of experiment } & \multicolumn{4}{|c|}{ Yield (dry mass), t/ha } & \multicolumn{2}{|c|}{$\begin{array}{l}\text { Increase due } \\
\text { bacterization }\end{array}$} \\
\hline & $\begin{array}{c}2014 \mathrm{p} \text {. } \\
\text { (in total for } \\
\text { two slopes) }\end{array}$ & $\begin{array}{c}2015 \mathrm{p} . \\
\text { (in } \\
\text { total for four } \\
\text { slopes) }\end{array}$ & $\begin{array}{c}2016 \text { p. } \\
\text { (one slopes) }\end{array}$ & $\begin{array}{l}\text { in total for } \\
\text { three years }\end{array}$ & $\mathrm{t} / \mathrm{ha}$ & $\%$ \\
\hline \multicolumn{7}{|c|}{ without bacterization } \\
\hline $\begin{array}{l}\text { Without fertilizers, } \\
\text { control }\end{array}$ & 2,42 & 7,50 & 2,58 & 12,50 & - & - \\
\hline $\mathrm{N}_{30} \mathrm{P}_{30} \mathrm{~K}_{30}$ & 2,68 & 8,12 & 2,79 & 13,59 & - & - \\
\hline $\mathrm{N}_{60} \mathrm{P}_{60} \mathrm{~K}_{60}$ & 2,80 & 8,65 & 3,00 & 14,45 & - & - \\
\hline $\mathrm{N}_{90} \mathrm{P}_{90} \mathrm{~K}_{90}$ & 3,00 & 8,84 & 3,08 & 14,92 & - & - \\
\hline $\mathrm{N}_{120} \mathrm{P}_{120} \mathrm{~K}_{120}$ & 3,16 & 9,00 & 3,15 & 15,31 & - & - \\
\hline Cattle manure, 25 t/ha & 2,63 & 8,15 & 2,90 & 13,68 & - & - \\
\hline $\begin{array}{l}\text { Cattle manure, } \\
12,5 \text { t/ha }+\mathrm{N}_{30} \mathrm{P}_{30} \mathrm{~K}_{30}\end{array}$ & 2,76 & 8,52 & 2,96 & 14,24 & - & - \\
\hline Biocompost, 12,5 t/ha & 2,73 & 8,36 & 2,96 & 14,05 & - & - \\
\hline Plant remnants & 2,40 & 7,65 & 2,80 & 12,85 & - & - \\
\hline \multicolumn{7}{|c|}{ bacterization with Rhizobofit } \\
\hline Without fertilizers & 2,75 & 8,05 & 2,95 & 13,75 & & 10,0 \\
\hline $\mathrm{N}_{30} \mathrm{P}_{30} \mathrm{~K}_{30}$ & 2,97 & 9,60 & 3,10 & 15,67 & 2,08 & 15,3 \\
\hline $\mathrm{N}_{60} \mathrm{P}_{60} \mathrm{~K}_{60}$ & 3,15 & 10,18 & 3,33 & 16,66 & 2,21 & 15,3 \\
\hline $\mathrm{N}_{90} \mathrm{P}_{90} \mathrm{~K}_{90}$ & 3,05 & 10,15 & 3,29 & 16,49 & 1,57 & 8,9 \\
\hline $\mathrm{N}_{120} \mathrm{P}_{120} \mathrm{~K}_{120}$ & 3,15 & 10,10 & 3,25 & 16,50 & 1,19 & 7,8 \\
\hline Cattle manure, 25 t/ha & 2,95 & 9,68 & 3,14 & 15,77 & 2,09 & 15,3 \\
\hline $\begin{array}{l}\text { Cattle manure, } \\
12,5 \text { t/ha }+\mathrm{N}_{30} \mathrm{P}_{30} \mathrm{~K}_{30}\end{array}$ & 3,10 & 10,00 & 3,22 & 16,32 & 2,08 & 14,6 \\
\hline Biocompost, 12,5 t/ha & 3,04 & 9,80 & 3,16 & 16,00 & 1,95 & 13,9 \\
\hline Plant remnants & 2,85 & 9,00 & 2,97 & 14,82 & 1,97 & 15,3 \\
\hline $\mathrm{LSD}_{05} \quad$ for experiment & 0,26 & 0,55 & 0,25 & & & \\
\hline for fertilizers & 0,14 & 0,28 & 0,14 & & & \\
\hline $\begin{array}{r}\text { for inoculation and } \\
\text { interaction }\end{array}$ & 0,13 & 0,28 & 0,12 & & & \\
\hline
\end{tabular}

The after-effects of organic fertilizers in different ways influenced the synthesis of protein. For example, under the cultivation of alfalfa in the background of the use of straw, as well as manure, we observe only a tendency to increase in parameters. However, organic and mineral fertilization and the after-effect of biocompost provided significant positive changes (Table 4).

Among the studied factors, the greatest influence on the synthesis of protein in alfalfa plants has the use of Rhizobofit. Pre-sowing bacterization contributed to the growth of the crude protein content in the green mass for all studied agricultural backgrounds without exception. However, indicators are most likely to increase with the use of microbial preparations on the following 
backgrounds: without fertilizers, $\mathrm{N}_{30} \mathrm{P}_{30} \mathrm{~K}_{30}, \mathrm{~N}_{60} \mathrm{P}_{60} \mathrm{~K}_{60}$, as well as under the after-effect of biocompost.

Table 4. Content protein («crude protein») in a dry mass of plants of alfalfa under influence of fertilizers and Rhizobofit, 2015, budding stage

\begin{tabular}{|l|l|}
\hline \multicolumn{1}{|c|}{ Variants of experiment } & Protein, $\%$ \\
\hline & without bacterization \\
\hline Without fertilizers, control & $18,4 \pm 0,3$ \\
\hline $\mathrm{N}_{30} \mathrm{P}_{30} \mathrm{~K}_{30}$ & $19,5 \pm 0,2$ \\
\hline $\mathrm{N}_{60} \mathrm{P}_{60} \mathrm{~K}_{60}$ & $19,7 \pm 0,3$ \\
\hline $\mathrm{N}_{90} \mathrm{P}_{90} \mathrm{~K}_{90}$ & $19,7 \pm 0,1$ \\
\hline $\mathrm{N}_{120} \mathrm{P}_{120} \mathrm{~K}_{120}$ & $20,0 \pm 0,5$ \\
\hline Cattle manure, 25 t/ha & $18,9 \pm 0,3$ \\
\hline Cattle manure, 12,5 t/ha $+\mathrm{N}_{30} \mathrm{P}_{30} \mathrm{~K}_{30}$ & $19,7 \pm 0,2$ \\
\hline Biocompost, 12,5 t/ha & $19,5 \pm 0,2$ \\
\hline Plant remnants & $18,4 \pm 0,5$ \\
\hline & $20,0 \pm 0,5$ \\
\hline Without fertilizers & $21,2 \pm 0,1$ \\
\hline $\mathrm{N}_{30} \mathrm{P}_{30} \mathrm{~K}_{30}$ & $21,3 \pm 0,4$ \\
\hline $\mathrm{N}_{60} \mathrm{P}_{60} \mathrm{~K}_{60}$ & $21,0 \pm 0,5$ \\
\hline $\mathrm{N}_{90} \mathrm{P}_{90} \mathrm{~K}_{90}$ & $21,1 \pm 0,2$ \\
\hline $\mathrm{N}_{120} \mathrm{P}_{120} \mathrm{~K}_{120}$ & $20,8 \pm 0,2$ \\
\hline Cattle manure, 25 t/ha & $21,0 \pm 0,3$ \\
\hline Cattle manure, 12,5 t/ha $+\mathrm{N}_{30} \mathrm{P}_{30} \mathrm{~K}_{30}$ & $20,9 \pm 0,1$ \\
\hline Biocompost, 12,5 t/ha & $19,5 \pm 0,3$ \\
\hline Plant remnants & \\
\hline & pacterization with Rhizobofit \\
\hline & \\
\hline & \\
\hline
\end{tabular}

The analysis of the parameters of the process of nitrogen fixation, the yield of culture and the content of protein in the plant mass can provide conclusions about the prospects of certain studied agricultural backgrounds in the manufacture. Thus, an increase in the normal ranges of mineral fertilizers over $\mathrm{N}_{60} \mathrm{P}_{60} \mathrm{~K}_{60}$ leads to decrease in the activity of the nitrogen fixation process and does not provide an appropriate return on investment by yield. In this case, the protein content remains practically the same as for the use of low fertilizer rates.

The after-effects of organic fertilizers have a positive effect on the levels of fixation of atmospheric nitrogen, yield of alfalfa, and the content of protein in the plant mass. The use of biocompost helps to achieve better performance than manure. It is also useful to use $\mathrm{N}_{30} \mathrm{P}_{30} \mathrm{~K}_{30}$ by the backdrop of manure. 
System application of plant remnants does not lead to a decrease in the studied parameters, which indicates in favour of the well-known thesis about the expediency of their use, provided that the crop rotation is saturated by legume grasses.

1. Биологические основы плодородия почв / [О.А. Берестецький,
[ Ю. М. Возняковская, Л. М. Доросинский и др.] - М. : Колос, 1984. - 287 с.

2. Кожемяков А. П. Продуктивность азотфиксации в агроценозах / А. П. Кожемяков // Мікробіол. журн. - 1997. - 59, №4. - С. 22-26.

3. Експериментальна грунтова мікробіологія / [В. В. Волкогон, О. В. Надкернична, Л. М. Токмакова та ін.] ; за ред. В. В. Волкогона. - К. : Аграрна наука, 2010. -464 c.

4. Корми, комбікорми, комбікормова сировина. Методи визначання вмісту азоту i сирого протеїну: ДСТУ 7169:2010 (зі скасуванням чинності в Україні ГОСТ 13496.4-93). — [Чинний від 2011-07-01]. - К. : Держспоживстандарт України, 2011. - 45 с. - (Національні стандарти України).

5. Доспехов Б. А. Методика полевого опыта с основами статистической обработки результатов исследований / Б. А. Доспехов - [5-е изд.]. - М. : Агропромиздат, 1985. — 351 с.

6. Визначення фізіологічно (екологічно) доцільних доз мінерального азоту в технологіях вирощування сільськогосподарських культур (науково-методичні рекомендації) / [І. В. Гриник, А. С. Заришняк, В. В. Волкогон та ін.]. - К., 2010. - 35 с.

7. Колбе Г. Солома как удобрение / Г. Колбе, Г. Штумбе. - М. : Колос, 1972. $88 \mathrm{c}$. 


\section{АКТИВНОСТЬ АЗОТФИКСАЦИИ В АГРОЦЕНОЗАХ ЛЮЦЕРНЫ И ПРОДУКТИВНОСТЬ КУЛЬТУРЫ ПОД ВЛИЯНИЕМ УДОБРЕНИЙ И МИКРОБНОГО ПРЕПАРАТА}

Центило Л.В.

Национальный университет биоресурсов и природопользования Украины МОН, г. Киев

В длительном полевом опыте на черноземе типичном изучено влияние различных систем удобрения и предпосевной бактеризации семян на активность симбиотической азотфиксаџии в агроиенозах лючернь и продуктивность культуры. Стимулирование прочесса фиксации атмосферного азота наблюдали при использовании минеральных удобрений в дозах, не превынаюших $N_{60} P_{60} K_{60}$, при их внесении в год посева. Высокие показатели нитрогеназной активности отмечены в условиях последействия навоза, компоста, органо-минерального удобрения (навоз + $\left.N_{30} P_{30} K_{30}\right), \quad$ a также систематического использования в севообороте растительных остатков. Растительная масса в отмеченных вариантах характеризовалась высоким содержанием белка. $B$ то же время, наибольшее влияние на синтез белка оказывало применение микробного препарата. Сочетание экологически приемлемых агрофонов $c$ предпосевной бактеризачией семян лючерны обеспечивало получение оптимальных показателей продуктивности культуры.

Ключевые слова: лючерна, системы удобрения, азотфиксация, содержание белка.

\section{АКТИВНІСТЬ АЗОТФІКСАЦІї В АГРОЦЕНОЗАХ ЛЮЦЕРНИ ТА ПРОДУКТИВНІСТЬ КУЛЬТУРИ ЗА ДІї ДОБРИВ ТА МІКРОБНОГО ПРЕПАРАТУ}

\section{Центило Л.В.}

Національний університет біоресурсів і природокористування України МОН, м. Київ

У тривалому польовому досліді на чорноземі типовому вивчено вплив різних систем удобрення та передпосівної бактеризачії насіння на активність симбіотичної азотфіксації в агроценозах люиерни та продуктивність культури. Стимулювання прочесу фіксачіi атмосферного азоту спостерігали за використання мінеральних добрив у дозах, щуо не перевищують $N_{60} P_{60} K_{60}$, за їх внесення в рік посіву. Високі показники нітрогеназної активності відмічено за післядії гною, компосту, органо-мінерального удобрення (післядія гною $\left.+N_{30} P_{30} K_{30}\right)$, а також за системного застосування в сівозміні рослинних решток. Рослинна маса $у$ зазначених варіантах характеризувалася високим вмістом білка. Проте найбільше на синтез білка впливало застосування мікробного препарату. Поєднання екологічно сприятливих агрофонів 3 передпосівною бактеризацією насіння лючерни забезпечувало отримання оптимальних показників продуктивності культури.

Ключові слова: лючерна, системи удобрення, азотфіксаиія, вміст білка. 